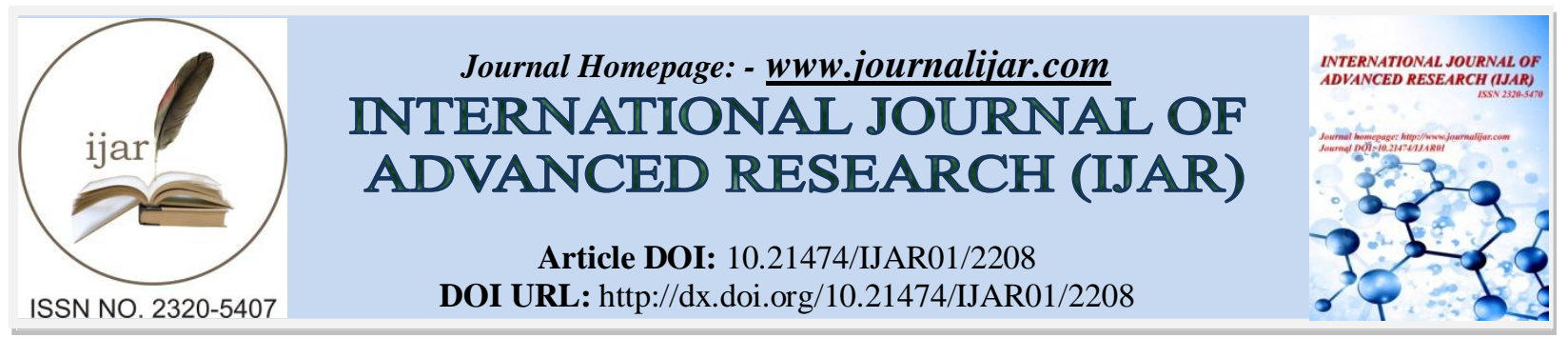

RESEARCH ARTICLE

\title{
LIPID PROFILES OF FIVE VARIETIES ARTOCARPUS SEED OILS BY GC-MS- A COMPARATIVE STUDY.
}

Nagala Sirisha* and Tamanam Raghava Rao.

Department of Biochemistry, College of Science and Technology, Andhra University, Visakhapatnam-530003, India.

\section{Manuscript Info}

Manuscript History

Received: 28 September 2016

Final Accepted: 30 October 2016

Published: November 2016

Key words:-

Artocarpus, essential fatty acids, GC-MS and seed oil.

\section{Abstract}

In recent years, the significance of polyunsaturated fatty acids analysis has gained much attention because of their various biological activities in health and disease, especially the n-3 and n- 6 fatty acids. The current proportional cram endeavors on providing qualitatively the fatty acid composition of hexane extracted seed oils of five Artocarpus species specifically Artocarpus heterophyllus, Artocarpus integrifolia, Artocarpus inscicus, Artocarpus hirsitus and Artocarpus integer. All the extracted oils were thick yellowish in colour having pungent odour with a yield of $40 \%$. Fallouts evidently indicate that the intricate fatty acid profile was experiential for A. integer with seven peaks subsequently $A$. heterophyllus through five peaks, next to that A.integrifolia and A.hirsitus by four peaks each, lastly A.inscicus seed oil had merely three peaks. Essential fatty acid 9, 12 Octadecadienoic acid, methyl ester $\left(\mathrm{C}_{19} \mathrm{H}_{34} \mathrm{O}_{2}\right)$ and 10 , 13Octadecadienoic acid, methyl ester $\left(\mathrm{C}_{19} \mathrm{H}_{34} \mathrm{O}_{2}\right)$ were found in all tested hexane seed oil free fatty acid methyl ester fractions except $A$. inscicus and in A. heterophyllus in that order. These findings demonstrated that essential oils of five Artocarpus species seeds were a complex mixture of numerous fatty acids and have great potential to be used as a source for natural health dietary products.

Copy Right, IJAR, 2016,. All rights reserved.

\section{Introduction:-}

Fatty acids are compounds synthesized in nature via condensation of malonyl coenzyme A units by a fatty acid synthase complex. Fatty acids act as building blocks of lipids. In general, they contain even numbers of carbon atoms in straight chains (usually in the range C14 to C24), although the synthases can also produce odd and branched chain fatty acids to some extent when supplied with the appropriate precursors; other substituent groups, including double bonds, are normally incorporated into the aliphatic chain later by different enzyme systems ${ }^{[1]}$.Fatty acids can either be saturated, monounsaturated or polyunsaturated depending on the number of double bonds ${ }^{[2]}$.

To analyze the fatty acid composition of food lipids, the complex lipids must be pre-treated so that the individual fatty acids are available for chromatographic analysis. Fatty acid components need to be converted into fatty acid methyl esters (FAME) in order to improve their volatility and thus ensuring better gas chromatographic peak shape ${ }^{[3]}$. FAME analysis of samples demands high chromatographic resolution because of the large number of positional and geometrical isomers of unsaturated fatty acids. Identification of the fatty acids is based on the retention times of 
FAME and the most common fatty acids are available in commercial reference mixtures. To confirm the identity of an analyte, gas chromatography-mass spectrometry (GC-MS) can be utilized in order to compare the mass spectrum with a reference spectrum stored in a computer database ${ }^{[4]}$. The present comparative study aims on providing qualitatively the fatty acid composition of hexane extracted seed oils of five Artocarpus species specifically Artocarpus heterophyllus, Artocarpus integrifolia, Artocarpus inscicus, Artocarpus hirsitus and Artocarpus integer.

\section{Materials and Methods:- \\ Extraction of oil by Soxhalation;-}

The Artocarpus heterophyllus, Artocarpus integrifolia, Artocarpus inscicus, Artocarpus hirsitus and Artocarpus integer hexane seed oils were extracted using soxhlet extraction method with analytical grade hexane as refluxing solvent. At the completion of the extraction process, the oils were recovered from the mixture by distillation and stored in dessicator until required to exploit ${ }^{[5]}$.

The percentage of oil content can be calculated as below

$\%$ of oil $=$ Wt. of oil obtained in gm. / Wt. of seed taken in gm. X 100

\section{Determination of fatty acid composition by GC-MS:-}

Fatty acid composition of hexane extracted seed oils specifically Artocarpus heterophyllus, Artocarpus integrifolia, Artocarpus inscicus, Artocarpus hirsitus and Artocarpus integer were determined using GC-MS according to the method described by Lepage and Roy ${ }^{[3]}$. Test seed oil samples $(20 \mathrm{mg})$ were separately mixed with $20 \mathrm{ml}$ of methanol and acetyl chloride (20:1, v/v) solution and to this $20 \mathrm{ml}$ hexane was added. Mixture was heated at $100^{\circ} \mathrm{C}$ for 30 mins under continuous stirring. After cooling to room temperature, $20 \mathrm{ml}$ of water was added and using separating funnel, the fatty acid methyl esters were extracted in hexanic layer. Three more extractions with hexane were made to ensure complete removal of methyl esters (REMI centrifuge, R-8C, India). The clear supernatant (2 $\mathrm{ml}$ ) was transferred to an auto sampler vial and injected with auto injector (AOC-20 i) into GC-MS for analysis. The GC-MS analysis carried out in a Shimadzu GC-MS-QP2010SE, equipped with a KRATOS mass detector model MS25RF (sector instrument) and a capillary column of $\mathrm{DB} \times \mathrm{LB}(30 \mathrm{~m} \times 0.32 \mathrm{~mm}, 0.50 \mu \mathrm{m}$ film thickness), carrier gas helium, constant pressure $90 \mathrm{kPa}$, split $1: 10$. The oven was programmed initially from $70^{\circ} \mathrm{C}$ with 2 min hold up time to the final temperature of $250^{\circ} \mathrm{C}$ with $5^{\circ} \mathrm{C} / \mathrm{min}$ ramp. The final temperature hold time was $20 \mathrm{~min}$. The inlet and GC/MS interface temperatures were kept at $250^{\circ} \mathrm{C}$ and $280^{\circ} \mathrm{C}$ respectively. The temperature of EI $70 \mathrm{eV}$ source was $200^{\circ} \mathrm{C}$ with full scan $(25-450 \mathrm{~m} / \mathrm{z})$, scan time $0.3 \mathrm{~s}$. The mass spectra of essential oil components were identified by comparing the mass spectra of the analytes with those of authentic standards from the mass spectra of Wiley 229.LIB and Mass Spectra Library NIST 05.LIB as well as on comparison of their retention indices of literature.

\section{Results:-}

The Artocarpus heterophyllus, Artocarpus integrifolia, Artocarpus hirsitus, Artocarpus inscicus and Artocarpus integer seed oil extraction was carried out by soxhlet extraction method as per the direction of AOAC 1998 (Association of Official Analytical Chemists). Hexane was used as solvent for extracting the oil from seeds and these were passed out for $10 \mathrm{hrs}$. All the extracted oils were thick yellowish in colour having pungent odour with a yield of $40 \%$. GC-MS analysis of the A. heterophyllus seed oil free fatty acid methyl ester fraction showed the presence of prominent five peaks indicating the presence of five compounds, namely methyl $-9,9,10,10-4-$ Octadecanoate (RT: 14.408 and Peak area: 2.42), no information available for its biological significance. Methyl Octadecanoate (RT:15.750 and Peak area:2.58), a saturated fatty acid, generally called as stearic acid, has an enormous variety of uses as an ingredient in food, cosmetics and in industrial products. It is also often used to change the consistency or melting temperature of a product, as a lubricant or to prevent oxidation ${ }^{[6]}$. 9Octadecenoic acid [Z] - methyl ester (RT: 15.952 and Peak area: 2.27), an unsaturated fatty acid, commonly entitled as oleic acid, methyl ester. It is used as a defoamer and solvent for inks and coatings and as a tar remover and as a raw material of emulsifiers or oiling agents for foods, spin finishes, surfactant and base material for perfume and solvent or co solvent and oil carrier in agricultural industry. 9, 12-Octadecadienoic acid, methyl ester (RT: 16.334 and Peak area: 2.63), familiarly called as linoleic acid, an essential omega-6-fatty acid. The main physiological requirement for omega-6-fatty acid is attributed to arachidonic acid. It is the major precursor of prostaglandins, leukotrienes and anandamides that play a vital role in cell signaling ${ }^{[2]}$. Z, E-3, 13-Octadecadien-1-ol (RT: 22.524 and Peak area: 90.10), feel right to pheromones chemical class. The GC-MS chromatogram and table were displayed in Fig. 1 and Table 1. In favour of A. integrifolia seed oil confirmed four peaks, representing the presence four compounds, explicitly Ecosanoic acid, methyl ester (RT: 14.397 and Peak area: 8.32), wax like solid, soluble in alcohol and ether, used in medical research and as a reference standard for gas chromatography. It is also known as 
specialty fatty acid. 9- Hexadecenoic acid, methyl ester [Z] (RT: 15.933 and Peak area: 7.93), frequently called as Palmitoleic acid, methyl ester. 9, 12 -Octadecadienoic acid, methyl ester (RT: 16.315 and Peak area: 8.91), conferred above and 10, 13- Octadecadienoic acid, methyl ester (RT: 22.447 and Peak area: 74.84), no information accessible for its significance. The GC-MS chromatogram and table were put on show in Fig. 2 and Table 2. Whereas A.hirsitus extracted seed oil free fatty acid methyl ester fraction showed four peaks, on behalf of the presence four compounds, namely 2-trifluromethyl - N- N- dimethyl 4 -nitroaniline (RT:3.758 and Peak area:2.14), no biological significance was established. 7-hexadecenoic acid, methyl ester [Z] (RT: 15.873 and Peak area: 2.23), commonly called as Palmitoleic acid methyl ester, Palmitoleic acid-based diets raise low-density lipoprotein cholesterol and diminish high-density lipoprotein cholesterol, even when dietary intake of cholesterol is maintained at a low level ${ }^{[7]}$. 9, 12 - Octadecadienoic acid, methyl ester (RT: 16.248 and Peak area: 2.98) and 10, 13 Octadecadienoic acid, methyl ester (RT: 22.386 and Peak area: 92.65), conferred above. The GC-MS chromatogram and tabular form were put on view in Fig. 3 and Table 3. Penultimate hexane extracted A.inscicus seed oil demonstrated three peaks, in support of the presence three compounds, they were Oxacycloheptadec -8-en-2-one (RT: 16.247 and Peak area:7.24), used as a flavour or fragrance ingredient. 2-ethoxythiazole (RT: 18.841 and Peak area: 6.71), used as a food flavor. 10, 13- Octadecadienoic acid, methyl ester (RT: 22.323 and Peak area: 86.05), discussed over. The GC-MS chromatogram and table were showed in Fig. 4 and Table 4. Finally for A. integer extracted seed oil displayed total seven peaks, all for the presence seven compounds, they were 2, 2, 6, 6 tetradenterio - 3, 7, diacetyl 3, 7 -diazadodecane (RT: 14.767 and Peak area:2.66), no biological impact was established. Benzo [1, 2-C: 3, 4- $\left.\mathrm{C}^{1}-5,6-\mathrm{C}^{11}\right]$ tris $[1,2,5]$ oxadiazole, 1, 4, 7 trioxide (RT: 15.133 and Peak area: 3.57), moderately toxic by ingestion, a mild skin and severe eye irritant. When heated to decomposition it emits acrid smoke and fumes. It used in explosives. Silane, dimethyl (3-hexyloxy) butoxy- (RT: 15.425 and Peak area: 2.25), no biological suggestions were obtainable for the compound and 9, 12 - Octadecadienoic acid [Z], methyl ester (RT: 15.814 and Peak area: 2.73), 9, 12- Octadecadienoic acid, methyl ester (RT: 16.187 and Peak area: 3.76), conferred above. 10, 13- Octadecadienoic acid methyl ester (RT: 22.233 and Peak area: 85.52) and 1, 2, 3 trimethoxy pentane (RT: 33.039 and Peak area: 2.51), both don't comprise biological impact. The GC-MS chromatogram and tabular form were exhibited in Fig. 5 and Table 5.

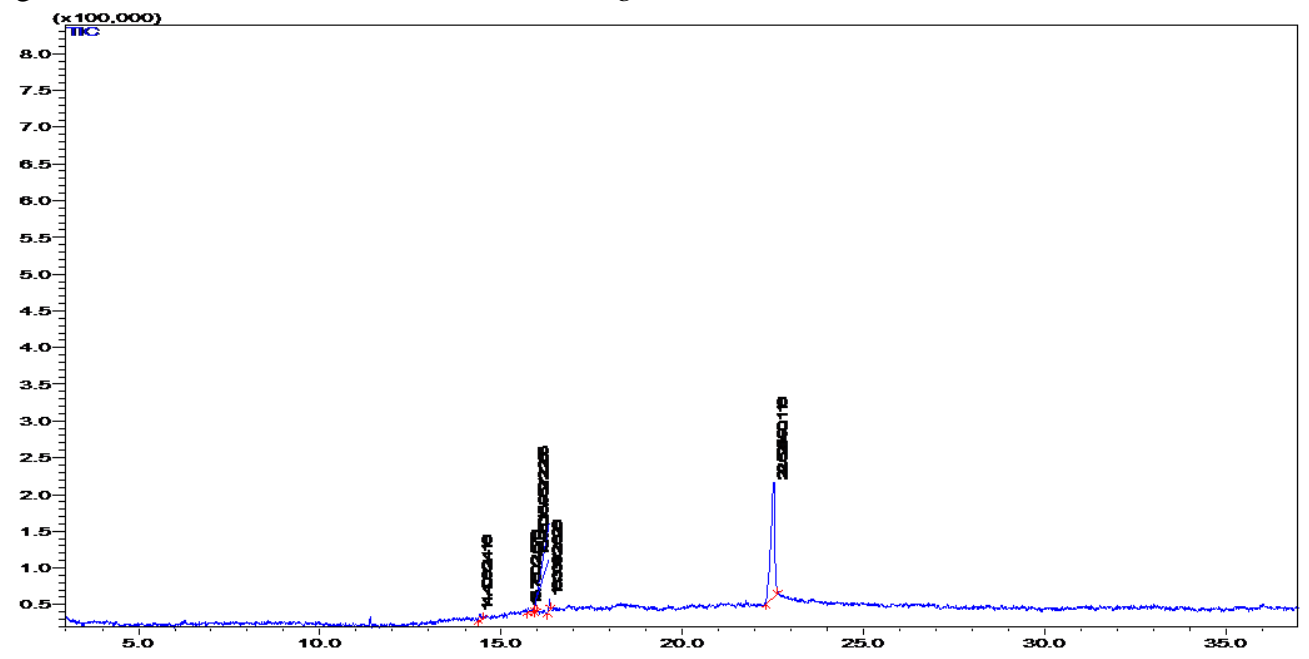

Figure 1:- GC-MS chromatogram of Artocarpuss heterophyllus hexane extracted seed oil

Table 1:-Total ionic chromatogram (GC-MS) of Artocarpuss heterophyllus hexane extracted seed oil obtained with temperature of EI $70 \mathrm{eV}$ using a capillary column of $\mathrm{DB} \times \mathrm{LB}$ with He gas as the carrier.

\begin{tabular}{|c|c|c|c|c|c|}
\hline S.No & RT & Name of the compound & $\begin{array}{c}\text { Molecular } \\
\text { formula }\end{array}$ & $\begin{array}{c}\text { Molecular } \\
\text { weight }\end{array}$ & $\begin{array}{c}\text { Peak } \\
\text { area \% }\end{array}$ \\
\hline 1 & 14.408 & Methyl - 9,9,10,10-4-Octadecanoate & $\mathrm{C}_{18} \mathrm{H}_{32} \mathrm{D}_{4} \mathrm{O}_{2}$ & 288.50 & 2.42 \\
\hline 2 & 15.750 & $\begin{array}{c}\text { Methyl Octadecanoate/ Stearic acid methyl ester/ } \\
\text { Octadecanoic acid, methyl ester }\end{array}$ & $\mathrm{C}_{19} \mathrm{H}_{38} \mathrm{O}_{2}$ & 298.50 & 2.58 \\
\hline 3 & 15.952 & $\begin{array}{c}\text { 9- Octadecenoic acid [Z]- methyl ester/ Oleic acid, } \\
\text { methyl ester/ Elaidic acid, methyl ester }\end{array}$ & $\mathrm{C}_{19} \mathrm{H}_{36} \mathrm{O}_{2}$ & 296.49 & 2.27 \\
\hline 4 & 16.334 & $9, \begin{array}{c}\text { 12-Octadecadienoic acid, methyl ester/ Methyl } \\
\text { linoleate/Linoleic acid, methyl ester }\end{array}$ & $\mathrm{C}_{19} \mathrm{H}_{34} \mathrm{O}_{2}$ & 294.47 & 2.63 \\
\hline 5 & 22.524 & Z, E-3,13-Octadecadien-1-ol & $\mathrm{C}_{18} \mathrm{H}_{34} \mathrm{O}$ & 266.46 & 90.10 \\
\hline
\end{tabular}




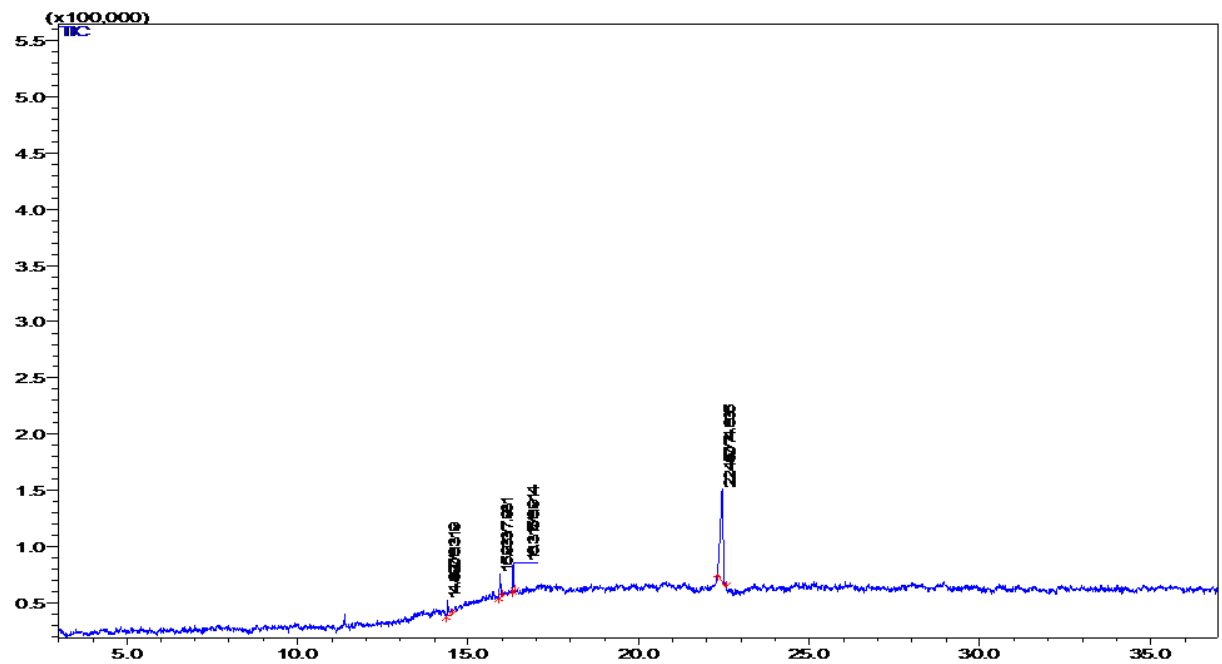

Figure 2:- GC-MS chromatogram of Artocarpuss integrifolia hexane extracted seed oil

Table 2:- Total ionic chromatogram (GC-MS) of Artocarpuss integrifolia hexane extracted seed oil obtained with temperature of EI $70 \mathrm{eV}$ using a capillary column of $\mathrm{DB} \times \mathrm{LB}$ with He gas as the carrier.

\begin{tabular}{|c|c|c|c|c|c|}
\hline S.No & RT & Name of the compound & $\begin{array}{c}\text { Molecular } \\
\text { formula }\end{array}$ & $\begin{array}{c}\text { Molecular } \\
\text { weight }\end{array}$ & $\begin{array}{c}\text { Peak } \\
\text { area \% }\end{array}$ \\
\hline 1 & 14.397 & $\begin{array}{c}\text { Ecosanoic acid, methyl ester [CAS] arachidic acid } \\
\text { methyl ester/ Methyl arachisate }\end{array}$ & $\mathrm{C}_{21} \mathrm{H}_{42} \mathrm{O}_{2}$ & 326.56 & 8.32 \\
\hline 2 & 15.933 & $\begin{array}{c}\text { 9- Hexadecenoic acid, methyl ester [Z]/ Methyl } \\
\text { palmitoleate/ Palmitoleic acid, methyl ester/ Methyl } \\
\text { palmitoleinate }\end{array}$ & $\mathrm{C}_{17} \mathrm{H}_{32} \mathrm{O}_{2}$ & 268.43 & 7.93 \\
\hline 3 & 16.315 & $\begin{array}{c}9,12-\text { Octadecadienoic acid, methyl ester/ Methyl } \\
\text { linoleate/Linoleic acid, methyl ester }\end{array}$ & $\mathrm{C}_{19} \mathrm{H}_{34} \mathrm{O}_{2}$ & 294.47 & 8.91 \\
\hline 4 & 22.447 & $10,13-$ Octadecadienoic acid, methyl ester & $\mathrm{C}_{19} \mathrm{H}_{34} \mathrm{O}_{2}$ & 294.47 & 74.84 \\
\hline
\end{tabular}

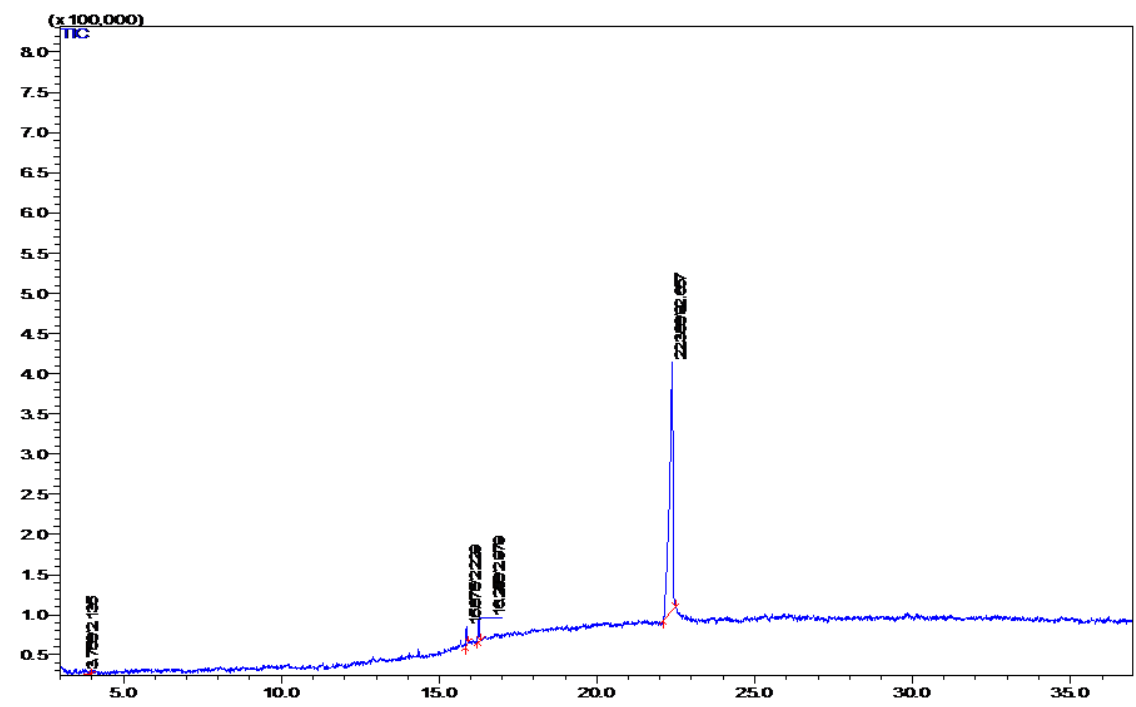

Figure 3:- GC-MS chromatogram of Artocarpuss hirsitus hexane extracted seed oil 
Table 3:- Total ionic chromatogram (GC-MS) of Artocarpuss hirsitus hexane extracted seed oil obtained with temperature of $\mathrm{EI} 70 \mathrm{eV}$ using a capillary column of $\mathrm{DB} \times \mathrm{LB}$ with $\mathrm{He}$ gas as the carrier.

\begin{tabular}{|c|c|c|c|c|c|}
\hline S.No & RT & Name of the compound & $\begin{array}{c}\text { Molecular } \\
\text { formula }\end{array}$ & $\begin{array}{c}\text { Molecular } \\
\text { weight }\end{array}$ & $\begin{array}{c}\text { Peak } \\
\text { area \% }\end{array}$ \\
\hline 1 & 3.758 & $\begin{array}{c}\text { 2-trifluromethyl - N- N- dimethyl 4-nitroaniline / N, } \\
\text { N-Dimethyl-4-nitro-2-trifluoromethylaniline / Benzene, } \\
\text { 1-trifluoromethyl-2-dimethylamino-5-nitro- }\end{array}$ & $\mathrm{C}_{9} \mathrm{H}_{9} \mathrm{~F}_{3} \mathrm{~N}_{2} \mathrm{O}_{2}$ & 234.18 & 2.14 \\
\hline 2 & 15.873 & $\begin{array}{c}7 \text {-hexadecenoic acid, methyl ester [Z]/ Palmitoleic acid } \\
\text { methyl ester }\end{array}$ & $\mathrm{C}_{17} \mathrm{H}_{32} \mathrm{O}_{2}$ & 268.44 & 2.23 \\
\hline 3 & 16.248 & $\begin{array}{c}9,12-\text { Octadecadienoic acid, methyl ester/ Methyl } \\
\text { linoleate/Linoleic acid, methyl ester }\end{array}$ & $\mathrm{C}_{19} \mathrm{H}_{34} \mathrm{O}_{2}$ & 294.47 & 2.98 \\
\hline 4 & 22.386 & 10,13 - Octadecadienoic acid, methyl ester & $\mathrm{C}_{19} \mathrm{H}_{34} \mathrm{O}_{2}$ & 294.47 & 92.65 \\
\hline
\end{tabular}

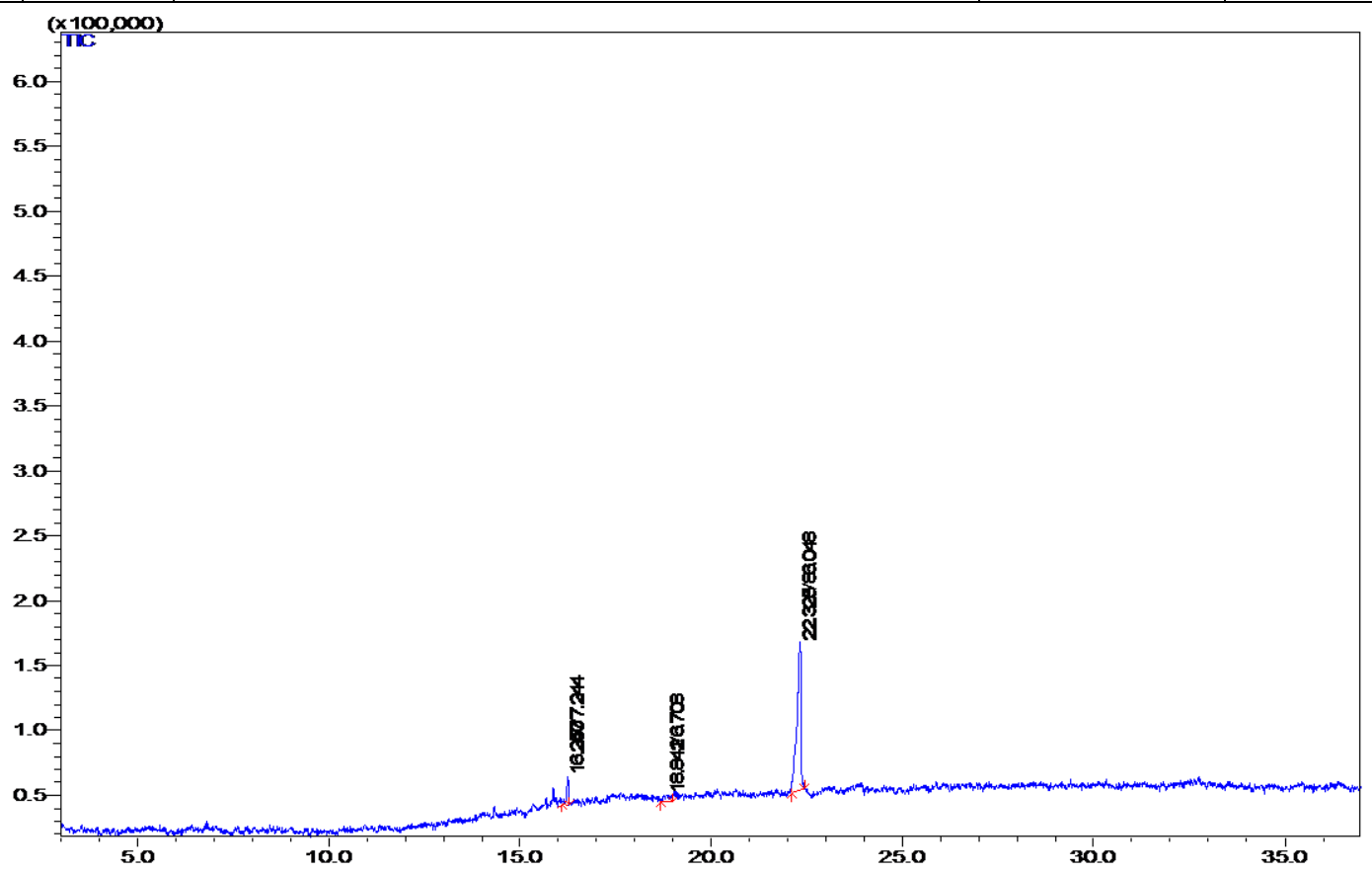

Figure 4:- GC-MS chromatogram of Artocarpuss inscicus hexane extracted seed oil

Table 4:-Total ionic chromatogram (GC-MS) of Artocarpuss inscicus hexane extracted seed oil obtained with temperature of $\mathrm{EI} 70 \mathrm{eV}$ using a capillary column of $\mathrm{DB} \times \mathrm{LB}$ with $\mathrm{He}$ gas as the carrier.

\begin{tabular}{|c|c|c|c|c|c|}
\hline S.No & RT & Name of the compound & $\begin{array}{c}\text { Molecular } \\
\text { formula }\end{array}$ & $\begin{array}{c}\text { Molecular } \\
\text { weight }\end{array}$ & $\begin{array}{c}\text { Peak } \\
\text { area \% }\end{array}$ \\
\hline 1 & 16.247 & Oxacycloheptadec -8-en-Z-one & $\mathrm{C}_{16} \mathrm{H}_{28} \mathrm{O}_{2}$ & 252.39 & 7.24 \\
\hline 2 & 18.841 & 2-ethoxythiazole & $\mathrm{C}_{5} \mathrm{H}_{7} \mathrm{NOS}_{1}$ & 129.18 & 6.71 \\
\hline 3 & 22.323 & 10,13 - Octadecadienoic acid, methyl ester & $\mathrm{C}_{19} \mathrm{H}_{34} \mathrm{O}_{2}$ & 294.47 & 86.05 \\
\hline
\end{tabular}




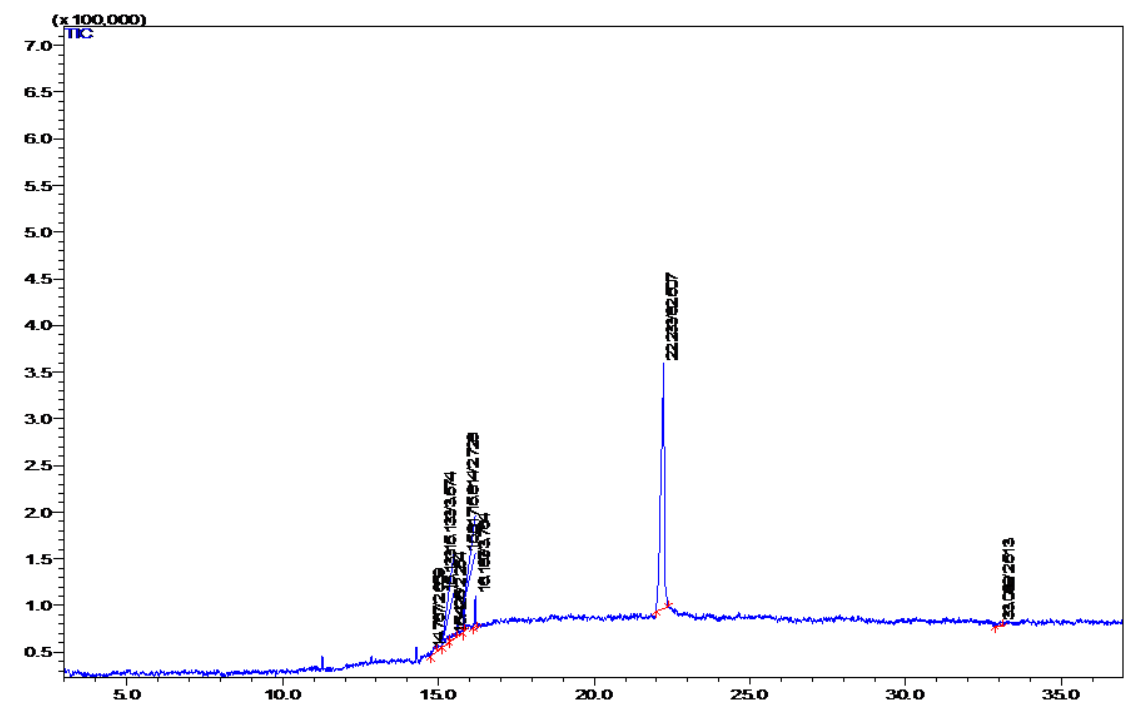

Figure 5:- GC-MS chromatogram of Artocarpuss integer hexane extracted seed oil.

Table 5:- Total ionic chromatogram (GC-MS) of Artocarpuss integer hexane extracted seed oil obtained with temperature of EI $70 \mathrm{eV}$ using a capillary column of $\mathrm{DB} \times \mathrm{LB}$ with $\mathrm{He}$ gas as the carrier.

\begin{tabular}{|c|c|c|c|c|c|}
\hline S.No & RT & $\begin{array}{c}\text { Name of the compound } \\
\text { Molecular } \\
\text { formula }\end{array}$ & $\begin{array}{c}\text { Molecular } \\
\text { weight }\end{array}$ & $\begin{array}{c}\text { Peak } \\
\text { area \% }\end{array}$ \\
\hline 1 & 14.767 & $2,2,6,6-$ tetradenterio - 3, 7, diacetyl 3, 7- \\
diazadodecane & $\mathrm{C}_{14} \mathrm{H}_{24} \mathrm{D}_{4} \mathrm{~N}_{2} \mathrm{O}_{2}$ & 256.0 & 2.66 \\
\hline 2 & 15.133 & $\begin{array}{c}\text { Benzo [1, 2-C: 3, 4- C1- 5, 6- C11] tris [1, 2, 5] } \\
\text { oxadiazole, 1, 4, 7 trioxide/ Benzenetrifuroxan/ } \\
\text { Benzotrifuroxan; Benzotris [c] furazan-2-oxide/ } \\
\text { Benzotris [1,2,5] oxadiazole, 1,4,7-trioxide/ BTF }\end{array}$ & $\mathrm{C}_{6} \mathrm{~N}_{6} \mathrm{O}_{6}$ & 252.10 & 3.57 \\
\hline 3 & 15.425 & $\begin{array}{c}\text { Silane, dimethyl (3-hexyloxy) butoxy- } \\
\text { linoleate/Linoleic acid, methyl ester }\end{array}$ & $\mathrm{C}_{12} \mathrm{H}_{28} \mathrm{O}_{2} \mathrm{Si}$ & 232.42 & 2.25 \\
\hline 4 & 15.814 & $\begin{array}{c}9,12-\text { Octadecadienoic acid, methyl ester/ Methyl } \\
\mathrm{C}_{19} \mathrm{H}_{34} \mathrm{O}_{2}\end{array}$ & 294.47 & 2.73 \\
\hline 5 & 16.187 & $\begin{array}{c}9,12-\text { Octadecadienoic acid, methyl ester/ Methyl } \\
\text { linoleate/Linoleic acid, methyl ester }\end{array}$ & $\mathrm{C}_{19} \mathrm{H}_{34} \mathrm{O}_{2}$ & 294.47 & 3.76 \\
\hline 6 & 22.233 & $10,13-$ Octadecadienoic acid methyl ester & $\mathrm{C}_{19} \mathrm{H}_{34} \mathrm{O}_{2}$ & 294.47 & 85.52 \\
\hline 7 & 33.039 & $\begin{array}{c}\text { Pentane 1, 2, 3- trimethoxy [CAS] 1, 2, 3- } \\
\text { trimethoxy pentane }\end{array}$ & $\mathrm{C}_{8} \mathrm{H}_{18} \mathrm{O}_{3}$ & 162.23 & 2.51 \\
\hline
\end{tabular}

\section{Discussion:-}

The significance of polyunsaturated fatty acids scrutiny has put on much interest because of their diverse natural tricks in wellbeing and illness, especially the $n-3$ and n- 6 fatty acids. These fatty acids play a vital role in the prevention and dealing of cardiovascular diseases, autoimmune diseases, eye sight and the improvement of learning ability ${ }^{[8]}$.

From the above outcomes evidently indicate that the intricate fatty acid profile was experiential for $A$. integer with seven peaks subsequently A. heterophyllus through five peaks, next to that A.integrifolia and A.hirsitus by four peaks each, lastly A.inscicus seed oil had merely three peaks. 9, 12 - Octadecadienoic acid, methyl ester $\left(\mathrm{C}_{19} \mathrm{H}_{34} \mathrm{O}_{2}\right)$ and 10,13- Octadecadienoic acid, methyl ester $\left(\mathrm{C}_{19} \mathrm{H}_{34} \mathrm{O}_{2}\right)$ were found in all tested hexane seed oil free fatty acid methyl ester fractions except $A$. inscicus and in A. heterophyllus correspondingly. Cheryan ${ }^{[9]}$ cited that the crude oil that is extracted from the oil seeds is a mixture of triacylglycerols, partial acylglycerols, free fatty acids, phosphatides, pigments, sterols and tocopherols (compounds that present vitamin E activity).

Previously various investigators worked out on diverse group of plant species for their fatty acid profiles by means of GC-MS. Ravi Kiran and Raghava Rao ${ }^{[10]}$ investigated lipid Profile of Ceiba pentandra seed oil by GC-MS and 
disclosed that Ceiba pentandra seed oil was complex mixture of numerous compounds, among them, palmitic acid appears to be the significant one along with essential fatty acid linoleic acid. It is also found that the Ceiba pentandra seed oil was comparable to cotton seed oil especially in the composition of palmitic and linoleic acids. Marimuthu Krishnaveni et al ${ }^{[11]}$ analyzed fatty acid profile of Gossypium seeds through GC-MS in order to unearth the fatty acids profile. Amongst the fatty acids studied, 9, 12-Octadecadienoic acid (Z, Z)-, 9, 12-Octadecadienoic acid (Z, Z)-methyl ester, Hexadecanoic acid methyl ester were found to be high. Traces of margaric acid methyl ester were also observed along with additional methyl esters. Vijisaral Elezabeth and Arumugam ${ }^{[12]}$ evaluated the chemical constituents of plant Indigofera suffruticosa leaves using GC-MS. The GC-MS analysis provided different peaks determining the presence of nine different phytochemical compounds namely pentadecanoic acid,14-methyl,methyl ester (5.86\%), n-hexanedecanoic acid (9.83\%), z-[13, 14-epoxy]tetradec-11-en-1-ol acetate (6.37\%), oleic acid (10.43\%), 9-octadecenoic acid[z]-,2-hydroxy-1-[hydroxyl methyl]ethyl ester (10.21\%), heptanoic acid, docosyl ester (6.28\%), octadecanoic acid, 7-hydroxy-, methyl ester (4.89\%), 6-octadecenoic acid[z]- (18.47\%) and 8octadecenoic acid, methyl ester (14.97\%). Syeda Farina Asghar et al ${ }^{[13]}$ explored petroleum ether extract (oil) of the whole plant Iris germanica with Gas chromatography-mass spectrometry (GC-MS) and identified eleven compounds specifically, 9-hexadecanoic acid methyl ester, 9-octadecenoic acid methyl ester, 8-octadecenoic acid methyl ester, 11-octadecenoic acid methyl, 10-octadecenoic acid methyl ester, 13-octadecenoic acid methyl ester, 16-octadecenoic acid methyl ester, 1,2-benzenedicarboxylic acid diisooctyl ester, bis (2- ethylhexyl) phthalate, methyl 6-methyl heptanoate and nonanoic acid, 9-oxo-methyl ester. The lipid fraction of Jatropha oil seed was extracted and analyzed by Emil Akbar et al ${ }^{[14]}$. The fatty acid composition of the extracted lipid revealed using the gas chromatography (GC). Both oleic acid (44.7\%) and linoleic acid (32.8\%) were detected as the dominant fatty acids while palmitic acid and stearic acid were the saturated fatty acids also found in the Jatropha oil.

\section{Conclusion:-}

Lipid profiles of five varieties Artocarpus seed oils by GC-MS showed that presence of biomedical components, which can be developed into top value-added materials of high-grade spice, cosmetic, food, and industrial chemical and solvent etc. our result as well benefit the development of new food sources and for the formulation of food supplements for the revival from malnutrition.

\section{References:-}

1. Christie WW. Lipid analysis, 3rd ed, The oily press. U.K, 2003.

2. Nelson D and Cox MM. Lehningers Principles of Biochemistry. WH Freeman. USA, 2013.

3. Lepage G and Roy C (1984) Improved recovery of fatty acid through direct transesterification without prior extraction or purification. J Lipid Res. 25:1391-139.

4. Gutnikov G. Fatty acid profiles of lipid samples [J]. J Chromatograph B, 1995, 671:71-89.

5. Popoola TOS, Yangomodou OD and Akintokun AK. Antimicrobial Activity of Cassava Seed Oil on Skin Pathogenic Microorganisms [J]. Res J Med Plant, 2007, 1: 60-64.

6. Emken Edward A. "Metabolism of dietary stearic acid relative to other fatty acids in human subjects"[J]. Am J Clin Nutr, 1994, 60 (6): 1023S-1028S.

7. Nestel P, Clifton $\mathrm{P}$ and Noakes M. Effects of increasing dietary palmitoleic acid compared with palmitic and oleic acids on plasma lipids of hypercholesterolemic men [J]. J Lipid Res, 1994, 35: 656-662.

8. Nielsen NS et al. Effect of structured lipids based on fish oil on the growth and fatty acid composition in rainbow trout (Oncorhynchus mykiss) [J]. Aquacult, 2005, 250: 411-423.

9. Cheryan M. Ultrafiltration and microfiltration handbook. Lancaster, Tecnomic. 1998.

10. Ravi Kiran Ch and Raghava Rao T. Lipid Profiling by GC-MS and Anti-inflammatory Activities of Ceiba pentandra Seed Oil [J]. J Biol Active Products from Nat, 2014, 4(1): 62-70.

11. Marimuthu Krishnaveni, Ravi Dhanalakshmi and Nagaraj Nandhini. GC-MS Analysis of Phytochemicals, Fatty acid Profile, Antimicrobial Activity of Gossypium Seeds [J]. Int J Pharm Sci Rev Res, 2014, 27(1): 273-276.

12. Vijisaral Elezabeth D and Arumugam S. GC-MS analysis of bioactive constituents of Indigofera suffruticosa leaves [J]. J Chem Pharm Res, 2014, 6(8):294-300.

13. Syeda Farina Asghar, Habib-ur-Rehman, Choudahry MI and Atta-ur-Rahman. Gas chromatography-mass spectrometry (GC-MS) analysis of petroleum ether extract (oil) and bio-assays of crude extract of Iris germanica [J]. Int J Genet Mol Bio, 2011, 3(7): 95 -100.

14. Emil Akbar, Zahira Yaakob, Siti Kartom et al. Characteristic and Composition of Jatropha Curcas Oil Seed from Malaysia and its Potential as Biodiesel Feedstock [J]. European Journal of Scientific Research, 2009, 29(3):396-403. 